\title{
EFEKTIVITAS PROGRAM WALK THRU DALAM PELAYANAN PEMBAYARAN PAJAK KENDARAAN BERMOTOR DI KANTOR BERSAMA SAMSAT KOTA PROBOLINGGO
}

\author{
Oleh : \\ Andhi Nur Rahmadi ${ }^{1}$, Risza Ulfia Wahyuni ${ }^{2}$ \\ Fakultas Ilmu Sosial dan Ilmu Politik, Program Studi Ilmu Administrasi Publik \\ Universitas Panca Marga Probolinggo \\ Email : Riszaulfia72@gmail.com
}

\begin{abstract}
Abstrak
Latar belakang masalah sebelum adanya program walk thru untuk wajib pajak mengalami kesulitan dalam melakukan sebuah pembayaran pajak kendaraan bermotor karena banyak layanan dari SAMSAT masih memerlukan waktu pemrosesan yang cukup lama sehingga wajib pajak harus meluangkan banyak waktunya yang terbuang untuk dapat melakukan proses pembayaran. Tujuan dalam suatu penelitian ialah mengetahui bahwa Efektivitas Program Walk Thru pada Pelayanan Pembayaran Pajak Kendaraan Bermotor di Kantor Bersama Samsat Kota Probolinggo. Jenis penelitiannya deskripif kualitatif dengan melakukan teknik pengumpulan datanya melalui cara observasi, wawancara singkat serta dokumentasi. Narasumber dalam wawancara singkat dalam penelitian ini adalah pegawai atau tenaga kerja sebagai penyedia layanan dari program Walk Thru. Dalam menganalisis sebuah data ini penulis menggunakan model secara interaktif. Hasil dari penelitian menunjukkan bahwasannya Efektivitas Program Walk Thru pada Layanan Pembayaran Pajak Kendaraan Bermotor di Kantor Bersama Samsat Kota Probolinggo dapat dikategorikan berjalan dengan efektif yaitu karena adanya pelaksanaan dari program yang pemahaman pada program, ketepatan pada sasaran, ketepatan pada waktu, pencapaian pada suatu tujuan dan perubahan nyata terhadap lingkungan yang termasuk kedalam kategori perubahan yang positif. Faktor pendukung dalam program dapat dilihat dari faktor external dan internal sementara untuk faktor penghambat berasal dari kuantitas (jumlah) dari pegawai atau tenaga kerja sebagai penyedia pelayanan pembayaran pajak kendaraan bermotor.
\end{abstract}

Kata Kunci: Efektivitas, Pelayanan Pembayaran, Program Walk Thru,

\section{PENDAhuluan}

Seiring dengan perkembangan zaman yang lebih maju saat ini, Pemerintah Kota Pobolinggo berupaya dalam mewujudkan kualitas pada bidang pelayanan pembayaran wajib pajak dengan tujuan untuk memberikan sebuah inovasi atau berupa update terbaru dalam meningkatkan pelayanan. Salah satu fungsi dari sebuah pemerintahan ialah adanya sebuah penyelenggaraan kegiatan pembangunan dan pelayanan. Oleh karena itu pemerintah bersama dengan masyarakat saling bekerja sama dalam mencapai suatu tujuan tersebut, yang dimana masyarakat sebagai obyek pendukung dalam mewujudkan suatu pelayanan dalam pemerintahan yang berkualitas maka di butuhkan adanya perubahan dalam melakukan suatu pelayanan publik, salah satunya yaitu dengan membentuk suatu 
program yang berorientasi secara langsung kepada masyarakat.

Salah satu program terbaru dalam meningkatkan pelayanan pada pembayaran pajak kendaraan bermotor adalah dengan penerapan program Walk Thru di Kantor bersama SAMSAT Kota Probolinggo. Program ini sudah diterapkan mulai Tahun 2017 dan hingga sampai saat ini keadaan program Walk Thru lebih banyak diminati oleh para wajib pajak dalam melakukan pembayaran pajakkendaraan bermotor. Karena tujuan dari adanya program ini yaitu dibuat berdasarkan kebutuhan dari masyarakat sehingga pemerintah dalam memberikan pelayanan publik harus sesuai dengan keinginan masyarakat serta harus menerapkan prinsip-prinsip pemerintahan yang ideal. Dalam melakukan fungsinya dengan baik maka pegawai pemerintahan harus bersifat profesional, bersifat aspiratif dan memiliki daya tanggap besar agar suatu program dalam pelayanan bisa berjalan dengan baik.

Dalam penelitian ini penulis akan berfokus pada keefektifan pada suatu program Walk Thru yang merupakan sebuah pencapaian yang akan di raih dalam organisasi pemerintahan sehingga bisa memudahkan masyarakat. Dalam mencapai tingkat keefektifan penulis mengukur dengan perbandingan antara suatu rencana dan target yang sudah matang di rencanakan sebelumnya dengan hasil yang telah diharapkan. Oleh karena itu, usaha dan hasil dari suatu program jika tidak tercapai sesuai dengan target maka dapat dikatakan masih belum berjalan efektif.

Berdasarkan pengamatan dari peneliti, sebelum adanya program Walk Thru untuk para wajib pajak mengalami beberapa kesulitan selama pembayaran pajak pada kendaraan bermotor karena berbagai layanan dari SAMSAT masih memerlukan waktu pemrosesan yang cukup lama sehingga wajib pajak harus meluangkan banyak waktunya yang terbuang untuk dapat melakukan proses pembayaran. Oleh karena itu sering kali wajib pajak mengabaikan dalam membayar pajak kendaraan bermotor terutama untuk para wajib pajak yang sedang sibuk dengan pekerjaan atau aktivitas lainnya.

Program ini diharapkan dapat memudahkan dan meminimalisir waktu dalam pembayaran pajak kendaraan bermotor sehingga para wajib pajak tidak lagi mengantri dengan antrian yang panjang untuk mendapatkan sebuah pelayanan. Jika dilihat dari keadaan pada sebuh Program Walk Thru sekarang lebih dipilih wajib pajak karena dengan pelaksanaanya yang mudah serta adanya proses waktu yang cepat jika dibandingkan dengan program lainnya maka Program Walk Thru lebih unggul saat malaksanakan 
pembayaran pada pajak kendaraan bermotor.

Maka dalam pemaparan dari permasalahan tersebut penulis tertarik melaksanakan sebuah penelitian dengan tujuan untuk mengetahui efektivitas dari pelaksanaan program Walk Thru serta mengetahui mengenai faktor pendukung dan faktor penghambat dalam pelaksanaan program Walk Thru pada Kantor Bersama SAMSAT Kota Probolinggo.

\section{TINJAUAN TEORITIS}

\subsection{Efektivitas}

Mahmudi (2010: 143), Efektivitas adalah perilaku dalam sebuah output yang memiliki tujuan atau suatu sasaran yang tepat. Dapat di katakan efektif jika dalam suatu usaha dalam kegiatan tersebut bisa mencapai tujuan akhir dan sasaran yang tepat dari program kebijakan.

Sutrisno $\quad(2007: 125-126), \quad$ ada beberapa indikator yang perlu diperhatikan dalam mengetahui keefektifan dari program kegiatan dalam pemerintahan sebagai berikut :

a. Paham suatu Program

Pada indikator program yaitu mengenai apa dari suatu program dapat terealisasikan sehingga dapat sangat mudah bisa di terima dan di pahami. Maksudnya adalah program walk thru tersebut dapat dijalankan dengan mudah dan efektif dalam proses pelaksanaannya.

b. Ketepatan Sasaran

Pada indikator ketepatan sasaran ini memerlukan peninjauan secara langsung di keberadaan program tersebut dilaksanakan. Program tersebut dapat dinilai ke dalam tepat sasaran dengan aturan yang berlaku. Ketika suatu pada program bisa di katakan efektif maka program tersebut telah berhasil melalui sasaran yang sudah ditentukan sebelumnya.

c. Ketepatan Waktu

Pada indikator ketepatan waktu ini dapat dinilai ketika pada program tersebut efektif apabila jika pelaksanaannya dari program tersebut telah berhasil melalui aturan pada waktu yang berlaku. Jika semakin tepat proses pelaksanaan pada program tersebut dilakukan maka dari itu juga semakin efektif dari program tersebut terealisasi.

d. Tercapainya Tujuan

Dari indicator tercapinya tujuan ini dapat dinilai dengan mengukur suatu keefektifan program dengan cara mengetahui akan tujuan yang bisa ditetapkan sebelumnya dan tujuan tersebut 
dapat tercapai. Jika semakin

besar manfaat dari program

tersebut berlangsung maka

semakin efektif pula tujuan yang

telah dicapai.

e. Perubahan Nyata

Pada indicator perubahan nyata ini dapat diukur dari aturan yang bisa ditetapkan sebelumnya serta dapat terealisasikan dengan baik yang dibuktikan dengan adanya suatu perubahan dalam masyarakat. Maka perubahan tersebut dapat di kategorikan menjadi perubahan secara positif dan secara negatif.

\subsection{Program}

Westra memiliki buku isinya tentang Manajemen dari sebuah Pembangunan Daerah (1983, hal.32) program yaitu pada semua langkah awal kali ataupun kegiatan sehingga akan bergantung menuju kedalam arah suatu pencapaian dan suatu tujuannya yang dapat di sebutkan. Program yaitu adanya sebuah tujuan dan akan berkembang dalam sebuah anggaran sehingga menyusun semua unsur penting bagi pelaksanaan yang tepat.

\subsection{Pelayanan}

a) Pelayanan publik

Dikutip dari suatu PERWALI nomor 168 Pasal 01 di tahun 2019 bahwasannya pengelolaan pengadaan layanan public pada lingkungan pemerintah kota probolinggo. Pelayanan Publik ialah pelaksanaan atau sebuah rangkaian kegiatan dengan tujuan dalam rangka memenuhi pelayanan yang stabil dan sesuai dari peraturan undang-undang bahwasannya pada tiap-tiap warga dan banyak penduduk dari suatu barang, jasa pada suatu layanan administrasi yang di berikan pada penyelenggaraan suatu layanan publik.

b) Pelayanan pada pajak

Berdasar ketentuan-ketentuan dari sebuah pasal 1 PMK 29/2020, yaitu bahwasannya pelayanan administrasi pada suatu perpajakan ialah ada kegiatan sebuah susunan kegiatan di laksanakan untuk memenuhi kebutuhan layanan yang sifatnya secara eksternal sehingga sesuai pada suatu aturan undangundang pada suatu bidang perpajakan untuk melaksanakan suatu hak dalam memenuhi kewajiban perpajakan dalam intinya mengharuskan penerbitan pada suatu produk hukum dari Direktorat Jenderal Pajak. Pada suatu ketentuan Pasal 1 PMK 29/2020, wajib pajak ialah seseorang yang sifatnya pada 
pembayar pajak, pada pemotong perpajakan, serta pemungutan perpajakan, dalam mempunyai suatu hak dan suatu kewajiban dalam perpajakan tepat dalam hal aturan perundang-undangan pada suatu bidang perpajakan.

\subsection{Pajak}

Undang-Undang No. 28 Tahun 2007 tentang Ketentuan Umum dan Tata Cara Perpajakan (KUP), pajak merupakan suatu kontribusi wajib kepada negara yang terutang oleh orang pribadi atau badan yang memiliki sifat dalam hal memaksa serta berdasar pada undang-undang, dengan tidak mendapatkan imbalan secara langsung serta digunakan untuk keperluan bagi negara dengan sebesar-besarnya untuk kemakmuran rakyat.

Dari definisi tersebut bahwa dapat disimpulkan pajak merupakan sebuah kontribusi yang harus dilaksanakan wajib pajak. Sehingga dalam Pasal 1 angka 2 tercantum mengenai UU KUP bahwa wajib pajak adalah orang pribadi atau badan, meliputi pembayar pajak, pemotong pajak, dan pemungut pajak, yang mempunyai hak dan kewajiban dalam hal perpajakan yang sesuai dengan ketentuan peraturan perundangundangan perpajakan.
Dalam rangka mendukung proses kegiatan dan kelancaran serta adanya tingkat penerima pajak kendaraan bermotor dan bea balik nama pada kendaraan bermotor, perlu diberikan biaya operasional. Biaya pada operasional yang sesuai pada ayat 1 bahwasannya ditetapkan oleh penerima pajak kendaraan bermotor dan bea balik nama kendaraan pada sepeda bermotor yang disetorkan pada Kas Daerah yang besarnya ditentukan sesuai dengan kemampuan pada keuangan Pemerintah Kota Probolinggo

\subsection{SAMSAT}

SAMSAT ialah sistem pada suatu kerjasama yang disusun dengan instansi Polri, Bappeda, dan PT Jasa Raharja (Persero) pada suatu layanan untuk menerbitkan STNK sehingga tanda nomor pada kendaraan bermotor berkaitan dalam pemasukan pada uang kas pada Negara baik dalam pajak kendaraan bermotor (PKB), pada bea balik nama pada kendaraan sepeda motor, serta adanya pada sumbangan yang sifatnya wajib pada dana kecelakaan lalu lintas jalan (SWDKLJJ), sehingga pada pelaksanaannya berada di kantor bersama samsat. Dalam suatu program walk thru yang ada di SAMSAT Kota Probolinggo ialah upaya dari pemerintah dalam mempermudah wajib pajak dalam perpanjangan STNK. Program ini bermanfaat dalam peningkatan layanan masyarakat. 


\section{METODE PENELITIAN}

Pada suatu penelitian di dalamnya menggunakan jenis penelitian secara deskriptif kualitatif. Lokasi dalam penelitian di lakukan di Kantor Bersama SAMSAT Kota Probolinggo. Untuk penelitiannya berfokus didasarkan pada Teori Efektivitas Menurut Sutrisno dalam Wulandari (2018:16) yang terdiri pada 5 indikator diantaranya adalah pemahaman pada program, ketepatan pada sasaran, ketepatan pada waktu, pencapaian suatu tujuan dan perubahan yang nyata. Sehingga adanya sumber data yang diperoleh dalam penelitian yaitu melalui sumber data primer dan sekunder. Agar dapat menyusun suatu informasi dengan logis maka dilakukan teknik pengumpulan data melalui wawancara singkat, observasi, serta adanya dokumentasi di lokasi penelitian. Setelah data disusun dengan logis maka perlunya menganalisis data agar data yang diperoleh lebih akurat maka dalam penelitian ini analisis data menggunakan model analisis interaktif dari Matthew B.Miles dan A.Michel Huberman (1992:20) ialah adanya pengumpulan data, reduksi pada data, penyajian pada data, serta adanya penarikan pada kesimpulan yang menjawab suatu permasalahan dalam penelitian.

\section{HASIL DAN PEMBAHASAN}

Hasil dalam penelitian ini akan dihubungkan dengan beberapa indikator pada efektivitas suatu program dalam pemerintahan mengenai bagaimana Efektivitas Pada Program Walk Thru Dalam Pelayanan Pembayaran Pajak Kendaraan Bermotor di Kantor Bersama SAMSAT Kota Probolinggo yang bertujuan untuk meningkatkan pelayanan publik melalui dukungan dari masyarakat secara langsung.

Samsat merupakan kepanjangan dari Sistem Administrasi Manunggal di Bawah Satu Atap, yang merupakan sistem pada kerja sama yang padu dengan instansi Polri, Bapedda dan PT. Jasa Raharja (Persero). Dalam memberi sebuah pelayanan publik kepada wajib pajak. Pemerintah Kota Probolinggo telah menerapkan beberapa program pelayanan di Kantor SAMSAT salah satunya adalah Program Walk Thru yang merupakan salah satu program tebaru dari SAMSAT Kota Probolinggo.

Sesuai hasil wawancara singkat dengan beberapa narasumber di lokasi penelitian, Maka diperoleh hasil yang berkaitan dengan adanya penelitian. Secara singkat hasil wawancara pada informan pegawai pada bidang pelayanan pembayaran pajak yaitu mengenai waktu pelayanan yang di berikan Kantor SAMSAT bagi wajib pajak yang akan 
melakukan pembayaran bisa dilaksanakan di hari Senin s/d Kamis pukul 08.00-12.00 WIB. Sementara untuk hari Jumat pukul 08.00-11.00 WIB. Untuk prosedur dalam menggunakan program layanan dari Walk Thru adalah wajib pajak bisa datang di kantor bersama SAMSAT Kota Probolinggo dan melakukan antri pada lingkup halaman walk thru dengan membawa persyaratan berupa KTP asli dan STNK asli kepada pihak birokrasi pelayanan pembayaran pajak kendaraan bermotor (PKB). Fokus dalam penelitian ini mengacu pada teori Menurut Sutrisno dalam Wulandari (2018:16) yang terdiri dari 5 indikator yaitu :

\section{a. Pemahaman Program}

Berdasarkan pada penelitian pemahaman pada program Walk Thru ini dapat dilihat dari pihak yang melakukan proses dalam pelayanan pembayaran pajak kendaraan bermotor yang telah mengetahui secara menyeluruh dan telah paham mengenai apa yang harus di lakukan dalam bidang pelayanan sehingga program Walk Thru dapat terlaksana dengan baik. Begitu pula dengan keefetifan pada pelaksanaan sebuah program maka wajib pajak juga harus ada pemahaman atas penerapan pada program tersebut atas apa yang telah diarahkan dari pegawai pelayanan. Misalnya pihak pelayanan pada program Walk Thru ini dapat menjelaskan kepada wajib pajak mengenai prosedur dan persyaratan secara jelas dalam program tersebut. Sehingga program tersebut mudah dipahami dan di mengerti serta prosesnya juga tidak akan membingungkan para wajib pajak. Pada alternative lain, kantor SAMSAT telah menyediakan beberapa poster mengenai prosedur dan persyaratan dalam memulai pembayaran pajak kendaraan bermotor sebagai berikut :

\section{Gambar 1.1 Kondisi Program} Layanan Walk Thru

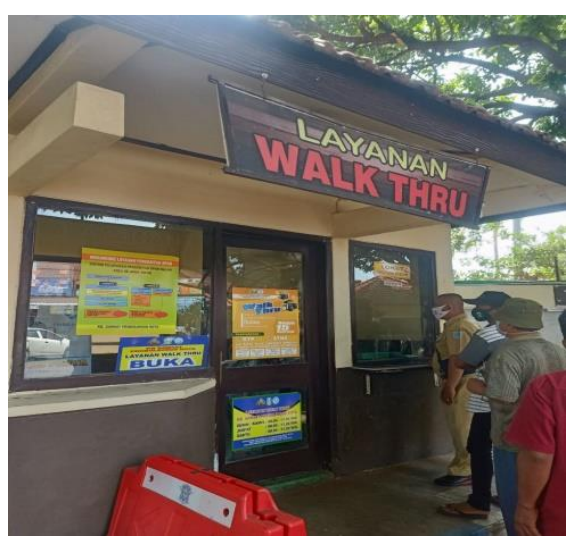

Sumber : SAMSAT Kota

Probolinggo

Dilihat dari adanya gambar 1.1 tersebut dapat diketahui bahwa persyaratan dalam pembayaran, prosedur penerapan bahkan jadwal operasional pelayanan pembayaran 
sudah disediakan dalam bentuk poster dilokasi penelitian. Dalam hal penerapannya maka pemahaman pada Walk Thru tersebut sudah dikatakan efektif.

\section{b. Ketepatan Sasaran}

Berdasarkan hasil dari penelitian bahwa pelaksanaan pada program Walk Thru sudah tepat sasaran karena termasuk ke dalam kebutuhan dan kondisi dari masyarakat sehingga pemerintah Kota Probolinggo terus memberikan yang terbaik salah satunya dengan pembentukan program terbaru yang dapat mempermudah kebutuhan masyarakat dalam melakukan pembayaran pajak kendaraan bemotor di kantor bersama SAMSAT.

\section{c. Ketepatan Waktu}

Berdasarkan dalam hasil penelitian program ini sudah termasuk ke dalam tepat waktu karena perencanaan pembangunan dimulai sejak tahun 2017 dan berjalan efektif hingga sekarang meskipun pada saat pandemi covid19 berlangsung program ini menjadi salah satu program unggulan dari SAMSAT. Layanan program Walk Thru memberikan akses kecepatan pada waktu pelayanan pembayaran dimana prosesnya hanya dilakukan kurang lebih hanya 15 menit. Para wajib pajak pun tidak akan antri panjang dalam melakukan pembayaran pajak kendaraan bermotor.

\section{d. Tercapainya Tujuan}

Berdasarkan dalam hasil penelitian tujuan dari adanya layanan terbaru yang di luncurkan pemerintah kota Probolinggo dengan obyek berada di kantor SAMSAT kota Probolingo ialah mempermudah bagi wajib pajak dalam pembayaran pajak kendaraan kendaraan bermotor. Tujuan utama dari pemerintah adalah mewujudkan sebuah bentuk pelayanan yang prima. Dengan harapan dari pemerintah kota Probolinggo program ini dapat membantu pelayanan lebih cepat, mudah serta tidak berkelit-kelit.

\section{e. Perubahan Nyata}

Berdasarkan dalam hasil peneltian dari penulis bahwa perubahanyang nyata terjadi berada di kategori perubahan secara positif. Perubahan yang nyata tersebut adalah masyarakat tidak malas lagi dalam melakukan pembayaran pajak kendaraan bermotor. Perubahan yang nyata jika di lihat dari segi pembangunan sarana dan 
prasarana di kantor SAMSAT yaitu dengan adanya pembayaran yang berada diluar kantor SAMSAT sehingga memudahkan masyarakat dalam melakukan proses pembayaran tanpa harus masuk kedalam kantor bersama SAMSAT dan juga para wajib pajak tidak akan lagi melakukan nomor antrian panjang yang biasanya dilakukan di dalam kantor SAMSAT.

\section{Faktor pendukung dan penghambat} adanya program walk thru :

a) Faktor pendukung

Adanya faktor pendukung internal berasal dari fasilitas yang di berikan kepada Pemerintah Kota Probolinggo dalam menunjang layanan program walk thru misalnya mengenai sarana dan prasarana yang sudah sangat lengkap. Sementara untuk faktor pendukung external adalah partisipasi masyarakat Kota Probolinggo dalam mendung adanya Program Walk Thru.

b) Faktor penghambat

Adanya faktor penghambat dari program Walk Thru adalah berasal dari kuantitas (jumlah) pegawai atau tenaga kerja sebagai penyedia pelayanan pembayaran masih berjumlah 1 pegawai/tenaga kerja.

\section{PENUTUP}

Jadi berdasarkan penjabaran dengan pembahasan tersebut bahwa Efektivitas Program Walk Thru dalam Proses Pembayaran Pajak Kendaraan Bermotor di Kantor Bersama Samsat Kota Probolingo sudah bisa di katakan sudah efektif dan berjalan dengan baik hingga sekarang. Hal itu tercermin dari adanya pelaksanaan pemahaman pada program yang telah di laksanakan adanya ketepatan pada sasaran, ketepatan pada waktu, keberhasilan pencapaian dalam tujuan, serta telah memberikan perubahan secara nyata oleh semua pihak yang ada di dalam suatu proses pelaksanaan program. Faktor pendukung dari external dan internal sementara untuk faktor penghambat berasal dari kuantita (jumlah) dari pegawai atau tenaga kerja sebagai penyedia pelayanan pembayaran pajak kendaraan bermotor.

Perlu adanya penambahan tenaga kerja dalam meningkatkan kualitas pelayanan menjadi semakin baik karena dengan berkembang pesatnya program walk thru jumlah wajib pajak yang menggunakan program walk thru yang belum sesuai pada jumlah tenaga kerja tersedia. 


\section{DAFTAR PUSTAKA}

Aliah, N. (2016). Strategi dalam Meningkatkan Pelayanan Melalui Website Pada Upt-P2T Bkpmd Provinsi Sulawesi Selatan. Jurusan Ilmu Administrasiuniversitas Hasanuddin Fakultas, 22.

Avidaniar Bintary, A. (2020). Analisis Kepatuhan bagi Wajib Pajak pada Kendaraan Bermotor tujuan dalam upaya Peningkatan Penerimaan pada Pajak Daerah pada Kantor Bersama Samsat Jakarta Timur Tahun 2015-2018. Jurnal Pajak Vokasi (JUPASI).

FEDYA ULFA, E. (2016). INOVASI PADA SUATU LAYANAN SAMSAT PROGRAM WALK THRU DALAM MEWUJUDKAN SUATU LAYANAN YANG PRIMA PADA KANTOR BERSAMA SAMSAT DI MOJOKERTO. Publika.

Handayaningrat, Soewarno, 2003. Sistem Pada Suatu Birokrasi Di Pemerintah. CV Mas Agung, Jakarta.

Haryani, T. N., \& Puryatama, A. F. (2020).

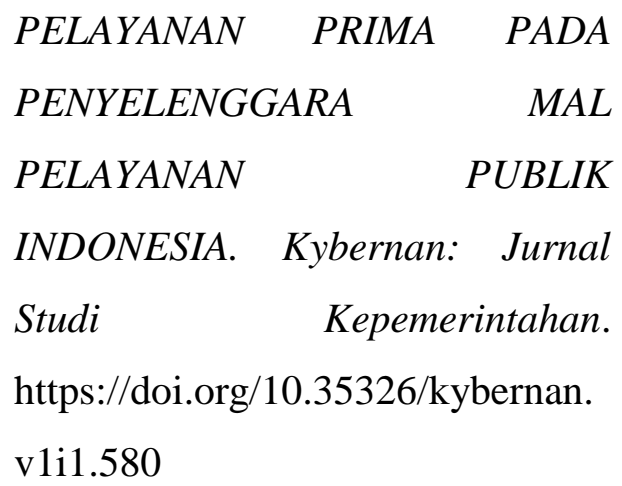

Keputusan Menteri Pendayagunaan pada Aparatur Negara Nomor 63/KEP/M.PAN/7/2003 mengenai Pedoman Untuk Publik Penyelenggaraan Layanan Publik

Pariata, Westra. (1983). Manajemen pada Pembangunan suatu Daerah. Jakarta, Ghalia Indonesia.

Peraturan Menteri Keuangan Nomor 29/PMK.03/2020 Pelaksanaan Pada Pelayanan Administrasi Pada Perpajakan Dalam Suatu Keadaan Kahar Berakibat Pada Pandemi Corona Virus Disease 2019 (PMK 29/2020)

Peraturan Walikota Kota Probolinggo Nomor 9 Tahun 2017 tentang Pedoman Penyusunan pada Standar Pelayanan dan Maklumat Pelayanan di Lingkungan Pemerintah Kota Probolinggo (Berita Daerah Kota Probolinggo Tahun 2017 Nomor 9);

Sen, R. (2019). Optimalisasi pada pelayanan pajak kendaraan bermotor pada kantor samsat kecamatan bayunglencir.

\section{Sumber Undang-Undang}

Undang-undang Nomor 18 Tahun 1997 tentang Pajak Daerah dan retribusi Daerah

Undang-undang Republik Indonesia Nomor 25 Tahun 2009 Tentang Pelayanan Publik. 